15. Ferromagnetic microtracers with multicolored code information and method of their identification / Barashkov N., Mohnke J., El-Fenni M.R., Eisenberg D., Eisenberg S. US Provisional Pat. Appl., 60/880,491, 2007.

16. Barashkov N. Iron-based microtracers and their use in feed applications / Barashkov N., Eisenberg D. // Suchasne materialoznavstvo ta tovaroznavstvo: teoriya, praktika, osvita : materiali i mizhnar. nauk.-prakt. internet-konferencï (m. Poltava, 26-27 lyutogo 2014 r.) - Poltava : PUET 2014. - c. 16-26.

17. Evaluation of homogeneity in feed by method of Microtracers ${ }^{\circledR} /$ Đuragić O., Lević J., Sredanović S., Lević Lj. Arch. Zootechn. 12 (2009) 85-91.

18. Jolanta B. Krolczyk. The effect of mixing time on the homogeneity of multi-component granular systems / Jolanta B. Krolczyk. // Transactions of famena XL-1 (2016) 45-56.

19. Corrigan O. I., Wilkinson M. L., Ryan J., Corrigan K. Harte \& O. F. The Use of Microtracers ${ }^{\circledR}$ in a Medicated Premix to Determine the Presence of Tiamulin in Final Feed Drug Development and Industrial Pharmacy. - Vol. 20. - 1994. - Issue 8. - P. 1503-1509.

20. Bagliacca G., Paci M., Marzoni E. Lisi Impiego di Particelle di Ferro Colorate (Microtracers) Come Traccianti Dei Mangimi E PER IL Controllo Della Miscelazione M. Large Animals Review, Anno 8, n. 1, Febbraio 2002. - P.1-4.

21. E. Trepalina. A. Galkin Test-sistemy dlja kontrolja ionofornykh kokcidiostatikov v kormakh «Kombikorma» №5, 2015. C.83-85.

Надійшла 09.09.2016. До друку19.09.2016 Адреса для переписки: вул. Канатна, 112, м. Одеса, 65039

УДК 636.085.55 - $021.62: 62-182.3: 331.482$

В.С. БРАЖЕНКО, канд. техн. наук, доцент, О.О. ФЕСЕНКО, канд. техн. наук, доцент Одеська національна академія харчових технологій, м. Одеса

\title{
КОМПЛЕКСНI ПРОЕКТНІ РІШЕННЯ НА ПЕРЕСУВНИХ КОМБІКОРМОВИХ АГРЕГАТАХ ТА ТЕХНІКА БЕЗПЕКИ ПРИ ЕКСПЛУАТАЦІЇ
}

\section{Анотація}

У статті проаналізовано сучасний стан інноваційних технологій виробницттва комбікормової продукиії та перспективи розвитку тваринництва та птахівництва в умовах фермерських господарств України. Одним із напрямків інтенсивного розвитку тваринництва та птахівництва є ефективне виробництво комбікормової продукції із застосуванням енергоефективних технологій та засобів ресурсозбереження. Впровадження інноваційних технологій та модернізачія підприємств комбікормової промисловості Украӥни дозволяють розширити асортимент високоякісної готової продукиії підвищеної продуктивної дії. Для ефективного застосування інноваційних технологій в умовах фермерських господарств $i$ за практичним досвідом роботи відомих виробників-фірм Західної Європи передбачено виробництво пересувних малогабаритних комбікормових агрегатів, устаткування.

Встановлено, щчо модернізація конструктивних елементів об'єктів, які поєднують декілька процесів, операцій y машинах, сприяє зменшенню характеристик металоємності й енергоємності. За рахунок поєднання основних $і$ допоміжних операцій досягається зменшення загальної маси конструкцій комбікормових агрегатів, питомих витрат енергії, спрощення монтажних і налагоджувальних робіт та покращення технічного обслуговування обладнання. Комплектність обладнання агрегатів дозволяє швидко регулювати способи контролю якості продукції $i$ застосовувати заходи щуодо підвищення якісних показників готової продукиії.

За аналізом досвіду роботи фахівців у проектних розробках варіантів побудови схем технологічних прочесів підготовки та виробництва комбікормової продукиії розроблено структурні схеми зв 'язку технологічних процесів та обладнання на пересувних комбікормових агрегатах.

Застосування технологічних процесів підготовки сировини та виробництва продукції максимально враховує потреби замовника за адресними комбікормами для сільськогосподарських тварин.

Виробництво комбікормової продукції на пересувних комбікормових агрегатах здійснюють на відкритому просторі та у закритому просторі, щуо потребує додаткової розробки вимог охорони прачі, правил пожежної безпеки, оскільки у господарствах зберігається велика кількість горючої рослинної сировини та продуктів ії переробки.

Інноваційні технічні рішення за проектними, конструкторськими розробками розиирюють сфери використання установки для переробки рослинних кормів і зернофуражу різної вологості, забезпечують стабільну пневмоподачу, знижують енергоємності в 1,5 ...2 рази, підвищують ефективність змімування компонентів до 85 ...98\%.

Ключові слова: комбікормові агрегати, технологічні прочеси, обладнання, комбікормова продукиія, правила пожежної безпеки. 
Інтенсивний розвиток тваринництва та птахівництва на теперішньому етапі розвитку комбікормової промисловості характеризується інтенсифікацією технологічних процесів, спрямованих на підвищення якості та асортименту комбікормової продукції. Комбікормова продукція за показниками поживної цінності повинна відповідати сучасним нормам годівлі високогенетичних порід, кросів тварин та птиці $[1,2]$. Інтенсивний розвиток тваринництва та птахівництва передбачає вирішення питань підвищення перетравності поживних речовин та продуктивної дії комбікормової продукції. Проблема створення оптимальної, біологічно обгрунтованої годівлі за науково обгрунтованим рецептом та його відповідності генотипу тварин, птиці загострюється в умовах фермерських господарств. Організація виробництва комбікормів повинна забезпечити повну переробку кормової сировини без втрат з отриманням готової продукції високої продуктивної дії за мінімальних витрат. Реалізація ефективних технологій виробництва комбікормової продукції, яка передбачає застосування сучасних установок, новітнього обладнання для всіх вікових груп сільськогосподарських тварин і птиці у фермерських, присадибних господарствах країни залишається актуальною проблемою. В ряді господарств, які мають ферми для утримання великої рогатої худоби, понад $35 . .40 \%$ зернофуражу у вигляді простої дерті застосовують на відгодівлю тварин, що призводить до перевитрат зернової сировини і збільшує собівартість тваринницької продукції [3, 4, 5]. Тому, для використання власної сировини при виробництві комбікормів у місцях вирощування зерна застосовують малогабаритні комбікормові агрегати: стаціонарні комбікормові агрегати з приводом від електродвигуна; самохідні мобільні комбікормові агрегати на шасі вантажного автомобіля; пересувні, причіпні малогабаритні агрегати з валом відбору потужності від трактора $[3,5]$.

Практичний досвід роботи фахівців свідчить, що для підвищення ефективності технологій виробництва комбікормів на пересувних малогабаритних агрегатах за конструкторськими розробками виконано модернізацію технологічного, транспортного обладнання. Так, основними складовими елементами комбікормових агрегатів є дробарка та змішувач. Тому ці об'єкти модернізуються як за морфологічними показниками, так і за функціональними, що відображають сукупність їх внутрішніх властивостей із застосуванням новітніх досягнень розвитку технічного рівня. Розробка спеціалізованих молоткових дробарок та змішувачів на підставі оптимального поєднання параметрів внутрішніх технічних рішень дозволяє на вході та виході машини пристосовуватися до конкретної потокової технологічної лінії, а також стати єдиним цілим із загальною структурою будови комбікормового агрегату та його функціонування. Аналіз принципів технологічного процесу подрібнення зерна та питомих витрат енергії під час роботи обладнання свідчить, що молоткові дробарки займають провідне становище для застосування в комбікормових агрегатах за їх потенційними можливостями щодо універсальності подрібнення різних видів кормової сировини, енергонасиченістю, довговічністю, простотою приводів. Для фермерських господарств доцільним $€$ застосування дробарок 3 центральною осьовою подачею матеріалу, оскільки їх конструкція дає можливість організувати самозабір зернової сировини із сховищ, супутнє відділення некормових домішок та вивантаження подрібненого продукту. Технологічні процеси завантаження, подрібнення та вивантаження виконуються за рахунок енергії пневмопотоків на вході в камеру подрібнення та на виході 3 неї. Дробарки 3 пристроями супутнього транспортування сировини, компонентів пневмопотоками знайшли широке застосування в складі потокових технологічних ліній приготування комбікормової продукції [4]. Вибір оптимальних варіантів проектних та конструкторських розробок щодо способів організації технологічних процесів дозування та змішування компонентів у комбікормових агрегатах виконується $з$ урахуванням вимог до якісного складу рецептів та забезпечення високої однорідності розподілу компонентів у складі готової продукції. Встановлено, що досягти отримання високоякісних показників комбікормової продукції можливо за умов застосування науково обгрунтованих рецептів із застосуванням вагового дозування та порційного змішування компонентів $[1,2]$. Такі завдання вирішуються комплексно шляхом установки змішувача на електронні терези та 3 використанням тензометричних датчиків, що забезпечує високу точність дозування.

На сьогодні широке впровадження в умовах фермерських господарств мають пересувні малогабаритні комбікормові агрегати, виробниками яких $\epsilon$ відомі зарубіжні фірми Riela, Daweke, Buschhof (Hiмеччина), Tropper (Австрія), Art's Way (США) [3, 5]. Офіційний представник торгової марки Riela в Україні - ТзОВ «Ріля Україна». Пересувні мобільні агрегати найчастіше застосовують у господарствах, де окремі види зернової сировини розташовані у різних складських приміщеннях. Такі агрегати дозволяють під'їхати до кожного складу та завантажити необхідну масу зерна, а також інші види сировину для підготовки та виробництва комбікормової продукції.

За аналізом досвіду експлуатації пересувних малогабаритних причіпних комбікормових агрегатів 3'ясовано, що проектні, конструкторські розробки передбачили застосування ресурсозбережних технологій на основі використання високоефективної техніки. Науково обгрунтований набір технічних об'єктів залежно від призначення дає змогу розв'язувати комплексні технічні завдання та поєднати технологічні і допоміжні процеси. Так, модернізація конструктивних елементів об'єктів, які поєднують декілька процесів, операцій у машинах, сприяють зменшенню характеристик металоємності і енергоємності. За рахунок поєднання основних і допоміжних операцій досягається зменшення загальної маси конструкції комбікормових агрегатів, питомих витрат енергії, спрощення монтажних і налагоджувальних робіт та покращення технічного обслуговування обладнання. Комплектність обладнання агрегатів дозволяє швидко регулювати способи контролю якості продукції і застосовувати заходи щодо підвищення якісних показників готової продукції $[3,4]$. 


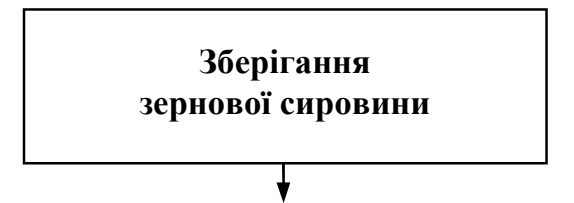

Склади підлогового типу для зберігання сировини насипом (ангари, навіси)

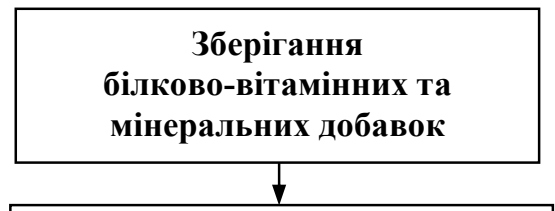

Склади підлогового типу для зберігання сировини в тарі (ангари, навіси)

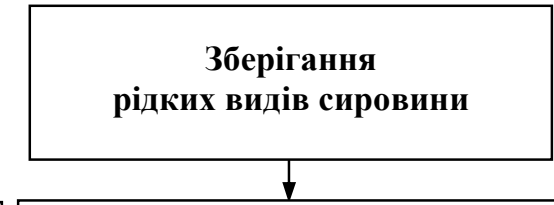

Металеві та пластикові контейнери у металевій захисній сітці

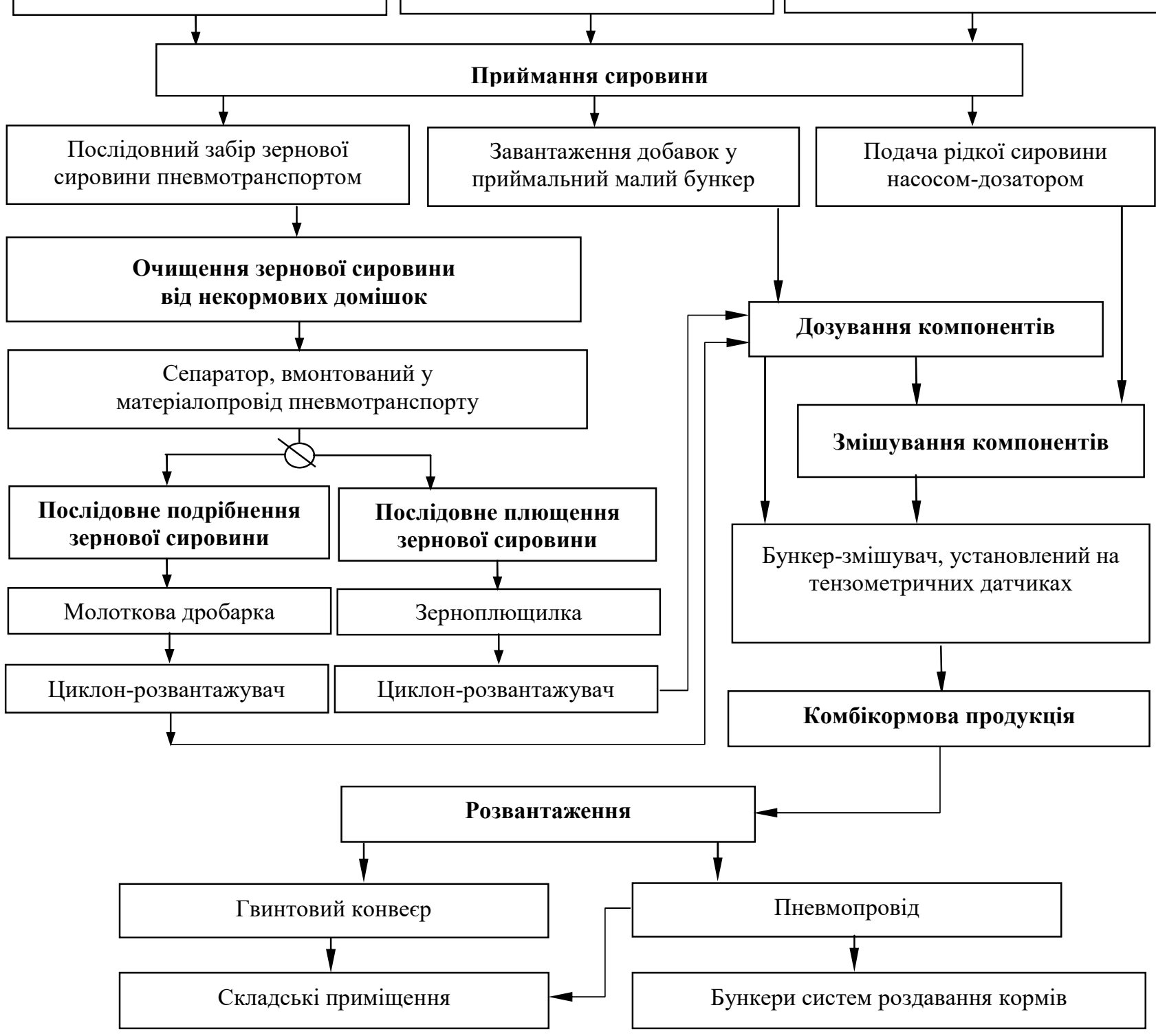

Рис. 1 - Структурна схема зв'язку технологічних процесів та обладнання при виробництві комбікормової продукцї̈ на пересувних комбікормових агрегатах

Пересувні комбікормові агрегати подібні за конструктивними рішення та мають комплект обладнання для: завантаження та очищення сировини; подрібнення сировини; плющення зернової сировини; дозування й змішування компонентів; дозування рідких видів сировини; вивантаження готового продукту. За аналізом технологічних, технічних, проектних рішень компонування обладнання на пересувних комбікормових агрегатах розроблено структурну схему зв'язку технологічних процесів та обладнання, яка наведена на рис. 1.

Технологія виробництва комбікормової продукції передбачає завантаження зернової сировина за допомогою забірника по завантажувальному пневмо- проводу. Очищення сировини від некормових домішок відбувається при завантаженні на сепараторі, який вмонтований у завантажувальний пневмопровід. Цей же пневмопровід транспортує сировину в молоткову дробарку. Подрібнена зернова сировина подається гвинтовим конвеєром 3 циклонарозвантажувача в бункер-змішувач. Варіант проектних розробок агрегатів 3 компонуванням зерноплющилки передбачає плющення зернобобової сировини для підвищення перетравності поживних речовин готової продукції. Подача білково-вітамінних добавок, преміксів та інших добавок, які не потребують подрібнення, здійснюється вручну, в окремий приймальний малий бункер. Компоненти послідовно 
надходять у ванну змішувача за масовою часткою відповідно до складу рецепту. Методом послідовного набору наважок компонентів відбувається процес вагового дозування, точність та стабільність якого застосовується за допомогою тензометричного пристрою, що передбачений на змішувачі. Установлено окремий дозувальний пристрій (насос-дозатор) для введення рідких видів сировини. Спостерігання за набором наважок компонентів передбачено як на індикаторі пульта управління, так і на табло, яке знаходиться в кабіні трактора. Дозовані компоненти змішуються у бункері-змішувачі 3 коректуванням раціональних режимів процесу залежно від складу рецепту відповідно до призначення продукції. Порція готової продукції за допомогою пневмотранспорту вивантажується в складські приміщення та в бункери, які розташовані на тваринницьких фермах безпосередньо для роздачі комбікорму сільськогосподарським тваринам. Сировина, продукція транспортується по пневмосистемі агрегату за допомогою потоку розрідженого повітря 3 компресора. Високий рівень автоматизації обладнання агрегату дозволяє керувати технологічними процесами на всіх етапах виробництва, для чого використовуються комп'ютерні

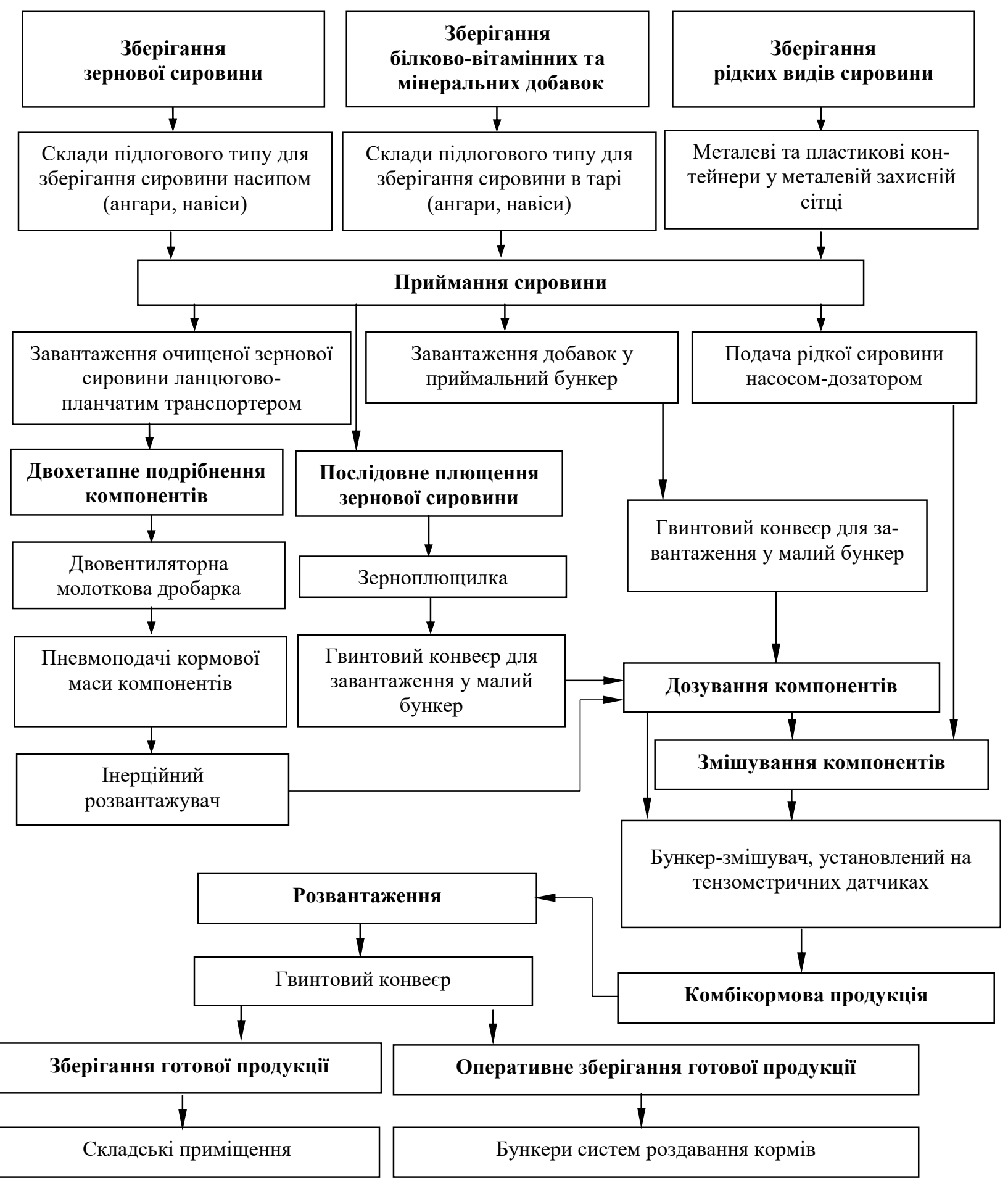

Рис. 2 - Структурна схема зв'язку технологічних процесів та обладнання при виробництві комбікормової продукції на причіпних комбікормових агрегатах 
технології з програмним забезпеченням для 99 рецептів комбікормової продукції. Технологія виробництва продукції максимально враховує потреби замовника за адресними комбікормами для сільськогосподарських тварин $[3,5]$. Зокрема, установка GMA 3500 виробництва фірми Riela (Німеччина) складається 3 одновісного ходу, сниці, дробарки, бункеразмішувача, приймального бункера для твердих добавок, дозувального пристрою для рідких компонентів та механізму приводу робочих органів. До іiі складу входить весь перелік обладнання для виробництва повноцінного комбікормового заводу, а комплексне компонування машин, устаткування за проектними розробками забезпечує компактність конструкції.

Пересувні агрегати з виробництва комбікормової продукції мають продуктивність $5 \ldots 7$ т/год. Комплект обладнання агрегату розташовано на одновісному причіпному шасі. Він приводиться в дію від валу відбору потужності трактора, зокрема потрібність у потужності досягає до 90 кВт. Питомі витрати енергії на виробництво 1 тонни готової продукції досягають до 12 кВт за годину [6]. Технологія виробництва продукції максимально враховує норми годівлі сільськогосподарських тварин відповідно до умов їх утримання $[3,5]$. Швидкість пересування агрегату на території фермерських господарств не перевищує $40 \mathrm{\kappa м} /$ год із застосуванням пневматичної гальмівної системи. Малогабаритний комбікормовий агрегат може працювати від автономного дизельного двигуна $[3,5]$.

Вдосконалення технологічних процесів підготовки сировини та модернізація обладнання із застосуванням розробки інноваційних технологій виконуються фахівцями відомих організацій, компаній, фірм країн СНД, Свропи. Так, фахівцями «ГНУ ВИЭCX Россельхозакадемии» (RU) виконано модернізацію молоткової дробарки та пристроїв для завантаження сировини, компонентів, а також перемішувального пристрою змішувача. За патентом на винахід причіпна установка для виробництва комбікормової продукції має раму, яка встановлена на одновісному шасі, двовентиляторну молоткову дробарку, зернову плющилку, малий приймальний бункер для білкововітамінних та мінеральних добавок, бункер-змішувач 3 інерційним завантажувачем компонентів [6]. Структурну схему зв'язку технологічних процесів та обладнання цієї установки наведено на рис. 2 .

Модернізація конструкції двовентиляторної дробарки за технічним результатом забезпечує двохетапний принцип подрібнення: спочатку відбувається подрібнення на фракції $100 \ldots 150$ мм шаблеподібними ножами, які встановлені в живильнику, при завантаженні рослинної сировини, а потім під впливом ударів молотків ротора в дробильній камері сировина подрібнюється на частки більш дрібного розміру (до 5...1,8 мм). Модернізація конструкції бункера-змішувача полягає в тому, що у верхній частині бункера-змішувача змонтовано камеру інерційного розвантажувача. Торцева частина стінок камери має два завантажувальних отвори для трубопроводів молоткової дробарки. Кожух шнека виконаний у вигля- ді порожнистої труби. У кожусі є прямокутні отвори 3 шарнірно закріпленими заслінками. Модернізації обладнання за технічними рішеннями відповідно до проектних, конструкторських розробок розширюють сфери використання установки для переробки рослинних кормів і зернофуражу різної вологості, забезпечують стабільну роботу пневмотранспорту, знижують енергоємності в 1,5...2 рази, підвищують ефективність технологічного процесу змішування компонентів до $85 \ldots 98 \%$.

За аналізом досвіду роботи фахівців з'ясовано, що необхідно дотримуватися вимог охорони праці, правил техніки та пожежної безпеки. Так, для експлуатації дизельного агрегату необхідно відвести спеціально майданчик або окреме приміщення. Установлювати дизельний генератор потрібно на рівну поверхню і фіксувати на фундаменті. Навколо генератора повинен бути вільний простір, щоб можна було підійти до устаткування без перешкод, зокрема площа приміщення не менше, ніж 15 м². У приміщенні повинна бути змонтована система вентиляції повітря для попередження перегріву дизельгенератора і система відводу відпрацьованих газів із приміщення, щоб уникнути їхнього накопичення та отруєння робочого персоналу. Для забезпечення заходів протипожежної безпеки необхідно дотримуватися наступного: робота дизель-генератора у вибухопожежному середовищі забороняється; дизель повинен знаходитися подалі від джерел вогню, а також бути захищеним від потрапляння всередину вологи і сторонніх предметів. Не можна заправляти дизельгенератор паливом за наявності поблизу джерел іскор і полум'я. При роботі дизельного генератора глушник і вихлопний сифон нагріваються до високих температур, тому всі легкозаймисті предмети слід тримати подалі від установки. При використанні дизельної електростанції поза приміщеннями слід встановлювати спеціальний навіс, зокрема контейнер, це дозволяє використовувати генератор узимку. Для підключення генератора треба використовувати кабель необхідного перетину та обов'язково заземлювати. При монтажі дизель-генератора у випадку виконання зварювальних робіт забороняється виконувати заземлення через корпус генератора, можливі ушкодження механізмів установки. При обслуговуванні і ремонті дизель-генератора необхідно вимикати пристрій від електромережі. Під час роботи 3 дизель-генератором потрібно надягати захисний спецодяг. Не треба заправляти бак паливом на працюючому двигуні, пролите паливо слід витирати, а одяг, який просочений паливом, слід зберігати в безпечному місці. Не треба запускати двигун, не установивши захисні грати.

Таким чином, високий рівень технічного забезпечення, автоматизації технологічних процесів підготовки сировини та виробництва комбікормової продукції, дотримання вимог охорони праці та техніки безпеки при експлуатації установок сприяють стабільності роботи обладнання та підвищують ефективність годівлі сільськогосподарських тварин. 


\section{ЛІТЕРАТУРА}

1. Сгоров, Б.В. Технологія виробництва комбікормів [Текст] : підручник для студ. вищ. навч. закладів / Б.В. Сгоров. - Одеса : Друкарський дім. - 2011. - 448 с.

2. Сгоров, Б.В. Технологія виробництва преміксів [Текст] : підручник / Б.В. Сгоров, О.І. Шаповаленко, А.В. Макаринська. - К.: Центр учбової літератури, 2007. - $288 \mathrm{c}$.

3. Перспективна технологія виробниитва комбікормів на пересувних комбікормових заводах [Електронний ресурс] / Режим доступу http://www.riela.com.ua/.../64-perspektyvna-tekhnolohiia-vyrobnytstva

4. Ачкевич, О.М. Еволючія технології та технологічних засобів приготування комбікормових сумішок на тваринницьких фермах України [Електронний ресурс] / O.М. Ачкевич. - Режсим доступу: http://www.rusnauka.com/27_NII.../35257.doc

5. Календрусь, I. Комбікорм на колесах [Електронний ресурс] / I. Календрузь, В. Ясенецький. - Режим доступу : http://propozitsiya.com

6. Прицепная установка для приготовления комбикормов и кормовых смесей (RU 2492775) [Електронний ресурс] / Режим доступу : http://www.findpatent.ru/patent/249/2492775.html

7. Підприсмства, будівлі і споруди по зберіганню та переробиі зерна : ДБН В.2.2-8-98. - [Чинний від 1998-01-07]. - Київ : Держбуд України, 1998. - 88 c. - Режсим доступу : http://dbn.at.ua/load/normativy/dbn/1-1-0-391.

8. Правила безпечної експлуатачї̈ електроустановок : НПАОП 40.1-1.01-97. - [Чинний від 1998-13-01]. - Київ : Держнаглядохоронпраиі Украӥни. Мін'юст Украӥни, 1998. - 23 с. - Режим доступу : http://zakon4.rada.gov.ua/laws/show/z0011-98.

9. Правила безпечної експлуатачії електроустановок спожсивачів (ДНАОП 00-1.21-98) : НПАОП 40.1-1.21-98. - [Чинний від 1998-1002]. - Київ : Держнаглядохоронпрачі України. Мін'юст України, $1998 . \quad$ - 25 с. - Режим доступу http://zakon4.rada.gov.ua/laws/show/z0093-98

\section{- - \\ V.E. BRAZHENKO, PhD, Sc, Sciences, Associate Professor, O.O. FESENKO, PhD, Sc, Sciences, Associate Professor, Odessa National Academy of Food Technologies \\ COMPLEX DESIGNED SOLUTIONS ON MOVABLE MIXED FODDER AGGREGATES AND SAFETY MEASURES DURING OPERATION}

\section{Abstract}

The modern condition of innovative technologies of mixed fodder production and prospects of livestock farming and poultry farming development in the conditions of farming in Ukraine, has been analyzed in the article. One of the directions of the intensive development of livestock farming and poultry farming is the efficient production of mixed fodders with application of power - efficient technologies and the ways of resource - saving. Introduction of the innovative technologies and modernization of enterprises of mixed - fodder industry of Ukraine allow to broaden the range of high - quality finished products of the increased productive effect. For efficient application of the innovative technologies in the conditions of farming and according to the practical experience of the famous producers of Western Europe companies, production of movable small mixed fodder aggregates, equipment, has been provided.

It has been stated, that modernization of constructive elements of the objects, which unite some processes, operations in the machine, contribute to decrease of the characteristics of metal capacity and power capacity. At the expense of uniting of the main and auxiliary operations, decrease of the total mass of mixed fodder aggregates constructions, specific energy expenses, simplification of assembly and adjusting operations and improving of the technical service of the equipment. Presence of a complete set of the equipment, aggregates allow to regulate the ways of controlling the quality of the production quickly and to apply measures for increase of the quality indices of the finished production.

According to the results of the experience of the specialists work in the designed elaborations of the variants of making the technological processes schemes of preparing and producing of mixed fodders, the structural schemes of the connection of the technological processes and equipment on the movable mixed fodder aggregates, have been developed.

Application of the technological processes of preparing of the raw material and further production take into account, at most, the demands of customer for direct mixed fodder farm animals.

The production of mixed fodders on the movable mixed fodder aggregates is carried out in the open and closed space, the additional development of the demands of labour protection, fire safety is necessary for it, because a great amount of fuel of the plant raw material and the products of its processing, is kept on the farms.

Innovative technical solutions of the designed developments broaden spheres of application of the plant for processing of plant fodders and grain fodder of various moisture, provide stable pneumatic supply, decrease power capacity by $1.5 \ldots 2$ times, increase efficiency of mixing the components to $85 \ldots 98 \%$.

Key words: mixed fodder aggregates, technological processes, equipment, mixed fodder production, rules of fire safety.

\section{REFERENCES}

1. Yegorov, B.V. Technology of mixed fodders production [Text] : Textbook for student of higher educational institutions / B.V. Yegorov. - Odessa : Publishing House, 2011. - 448 p.

2. Yegorov, B.V. Technology of premixes production [Text] : Textbook / B.V. Yegorov, O.I. Shapovalenko, A.V. Makarinskaya - K.: The Centre of educational literature, 2007. - 288 p.

3. The prospective technology of mixed fodder production on the movable mixed fodder plants. [Electronic resource] / Access : http://www.riela.com.ua/.../64-perspektyvna-tekhnolohiia-vyrobnytstva

4. Achkevich, O.M. Evolution of the technology and technological methods of preparing mixed fodder mixtures on the livestock farms of Ukraine [Electronic resource] / O.M. Achkevich. - Access : 
http://www.rusnauka.com/27_NII.../35257.doc

5. Kalendruz, I. Mixed fodder on the wheels [Electronic resource] / I. Kalendruz, B. Yasenetskiy - Access : http://propozitsiya.com

6. A trailer plant for preparing mixed fodders and fodder mixtures (RU 2492775) [Electronic resource] / Access : http://www.findpatent.ru/patent/249/2492775.html

7. Enterprises, buildings and constructions for keeping and grain processing: ДВN В.2.2-8-98. - [Valid since 199801-07]. - Kyiv : Dershbud of Ukraine, 1998. - 88 p. - Access : http://dbn.at.ua/load/normativy/dbn/1-1-0-391.

8. Rules of safe operation of electric plants: NPAOP 40.1-1.01-97. - [Valid since 1998-13-01]. - Kyiv : State labour protection of Ukraine. Ministry of Justice of Ukraine, 1998. - 23 p. - Access : http://zakon4.rada.gov.ua/laws/show/z0011-98.

9. Rules of safe operation of the customers electric plants (DNAOP 00-1.21-98) : NPAOP 40.1-1.21-98. - [Valid since 1998-10-02]. - Kyiv : State labour protection of Ukraine. Ministry of Justice of Ukraine, 1998. - 25 p. Access : http://zakon4.rada.gov.ua/laws/show/z0093-98

Надійшла 17.05.2016. До друку 24.05.2016

УДК 663.4.013.8:331.45

Irina Melnik, PhD, associate professor, Zinaida Saharova, senior lector,

Dasha Hnatovskaya, master

Odessa National Academy of Food Technologies, Odessa

\title{
LABOUR PROTECTION AND SAFETY IN THE BREWING INDUSTRY
}

\begin{abstract}
The article describes the quantification of the level of safety in the brewing industry, which allows determining the contribution of each employee to ensure healthy and safe working conditions. Factors have also been shown to affect the safety of each of the employees. Knowledge of the characteristics and limits of each of the factors makes it possible to secure workflow and solve potential problems early. Previously considered a comprehensive approach that allows full control of the security protecting the entire brewing industry.

Efficient and safe work is possible only if the working environment at the workplace to meet all the requirements of international standards in the field of occupational safety and health. Therefore, each category from a number of activities, which can significantly reduce the level of injury, and ending with the characteristics of each of the factors for drawing up a plan to ensure the maximum protection of the company's employees, was discussed. Chemical, physical, biological and psychophysical factors may exist alone or in combination with each other. It is therefore important to identify in advance all of them and to take all measures relating to ensure safe working conditions in each of the processes.

Separately considered optimal and allowable values of temperature, relative humidity and air velocity in the working area of industrial premises. The parameters were established for the purpose of continuous monitoring in order to ensure comfortable and safe work environment for each employee. In some cases it is necessary to consult with technicians to get the full picture of the possible threats posed by each type of equipment. Especially dangerous in terms of occupational safety and health in the brewing industry is a cooking workshop, where the air temperature in the working area is significantly increased, as well as the bottling plant (noisy).
\end{abstract}

Keywords: Safety, brewery, safe working conditions, safety, getting the wort.

\section{Introduction}

Assessment the level of occupational safety is one aspect of life safety, the most important task in the development, implementation and improvement of OSH management systems at the enterprises of the brewing industry and serves as a basis for effective functioning. Effective management of labor protection at the enterprise is possible only with quantitative assessment all levels of production. Necessary to distinguish the state of occupational safety and health of each individual worker (operator), the workplace and assessment with using the basic parameter - coefficient level of occupational safety and health, as well as evaluation of the work to ensure healthy and safe working conditions of officers, the level of labor protection led their divisions. Currently, there are two approaches to assessing the state of occupational safety and health in the workplace. The first is to determine the level of occupational safety factor structural unit as the arithmetic mean of the three factors and has significant shortcomings that hinder their widespread use in practice. The second approach to assessing the level of occupational safety and health on the site, in the workshop, and other departments, deprived of some of these disadvantages, is to evaluate the safety factor, which is determined by the heads of departments on a 